\title{
MORTALITY AND PROGNOSIS RELATED TO THE AMYLOIDOSIS OF STILL'S DISEASE
}

\author{
BY \\ MARGUERITE E. SMITH, BARBARA M. ANSELL, AND E. G. L. BYWATERS \\ M.R.C. Rheumatism Research Unit, Canadian Red Cross Memorial Hospital, Taplow, Maidenhead, Berks.
}

Amyloidosis in adult rheumatoid arthritis is well documented (Table I). Rosenberg, Baggenstoss, and Hench (1944) reported an incidence of 6.6 per cent. in a study of thirty post mortem cases and Unger, Zuckerbrod, Beck, and Steele (1948a) recorded a similar incidence ( 6.9 per cent. in 58 cases), but Teilum and Lindahl (1954) found it in 60.7 per cent. of 28 post mortem cases. Missen and Taylor (1956), reporting 47 cases from the Royal Postgraduate Medical School of London, and reviewing other large series in the literature, found a total of 385 cases and suggested $14 \cdot 7$ per cent. as a conservative estimate of the incidence of amyloidosis post mortem in adult rheumatoid arthritis. Fearnley and Lackner (1955) reported an incidence of 3.8 per cent. in 181 cases, using a modified Congo red test and liver biopsy for diagnosis, whereas Arapakis and Tribe (1963) found an incidence of 5.2 per cent. in 115 cases, using rectal biopsy for diagnosis.

TABLE I

REPORTED INCIDENCE OF AMYLOIDOSIS IN RHEUMATOID ARTHRITIS

\begin{tabular}{|c|c|c|c|}
\hline \multicolumn{2}{|r|}{ Series } & $\begin{array}{l}\text { No. } \\
\text { of } \\
\text { Cases }\end{array}$ & $\begin{array}{c}\text { Per cent. } \\
\text { with } \\
\text { Amyloidosis }\end{array}$ \\
\hline $\begin{array}{l}\text { Post } \\
\text { mortem }\end{array}$ & $\begin{array}{l}\text { Rosenberg and others, } 1944 \\
\text { Unger and others, } 1948 \mathrm{a} \\
\text { Teilum and Lindahl, } 1954 \\
\text { Missen and Taylor, } 1956\end{array}$ & $\begin{array}{r}30 \\
58 \\
28 \\
385\end{array}$ & $\begin{array}{r}6 \cdot 6 \\
6 \cdot 9 \\
60 \cdot 7 \\
14 \cdot 7\end{array}$ \\
\hline $\begin{array}{c}\text { Living } \\
\text { Patients }\end{array}$ & $\begin{array}{l}\text { Fearnley and Lackner, } 1955 \\
\text { Arapakis and Tribe, } 1963\end{array}$ & $\begin{array}{l}181 \\
115\end{array}$ & $\begin{array}{l}3 \cdot 8 \\
5 \cdot 2\end{array}$ \\
\hline
\end{tabular}

In Still's disease there have been numerous individual case reports (Trasoff, Schneeberg, and Scarf, 1944; James and Bolton, 1951 ; C.P.C. Boston, 1959; C.P.C. Hammersmith Hospital, 1964) and single juvenile cases have been reported among groups of adults (Reece and Reynolds, 1954; Parkins and Bywaters, 1959). In reviewing series of cases of Still's disease (Table II), Coss and Boots (1946) noted 1.8 per cent. in 56 cases, Edström (1958)
TABLE II

REPORTED INCIDENCE OF AMYLOIDOSIS IN STILL'S DISEASE

\begin{tabular}{|c|c|c|c|}
\hline Authors & Date & $\begin{array}{c}\text { No. } \\
\text { of } \\
\text { Cases }\end{array}$ & $\begin{array}{l}\text { Per cent. } \\
\text { with } \\
\text { Amyloidosis }\end{array}$ \\
\hline $\begin{array}{l}\text { Coss and Boots } \\
\text { Edström } \ldots \\
\text { Schlesinger and others } \\
\text { Lindbjerg } . .\end{array}$ & $\begin{array}{l}1946 \\
1958 \\
1961 \\
1964\end{array}$ & $\begin{array}{r}56 \\
161 \\
100 \\
75\end{array}$ & $\begin{array}{l}1 \cdot 8 \\
1 \cdot 2 \\
1 \\
4\end{array}$ \\
\hline
\end{tabular}

$1 \cdot 2$ per cent. in 161 cases, and Schlesinger, Forsyth, White, Smellie, and Stroud (1961) 1 per cent. in 100 cases. More recently Lindbjerg (1964) reported three deaths (4 per cent.) from this cause among the 75 cases discussed. These series are small and have a variable degree of bias due to hospital selection. With a much larger group followed personally for a much longer period, we have therefore assessed the incidence of amyloidosis in our own cases of juvenile rheumatoid arthritis and have also assessed the outcome following diagnosis.

\section{Material and Methods}

At the time of this study (1966), 389 cases of definite Still's disease* have been investigated and are being followed by this Unit. The follow-up is from 1 to 25 years (mean 10.9). Cases are seen routinely at least once a year until 10 years after onset, and then if the disease is inactive, at longer intervals unless review is requested by the general practitioner.

At each follow-up the whole disease process is graded as inactive, slightly active, or active, according to the presence or absence of pain and soft tissue swelling of the joints, due attention being paid to other features such as fever, rash, pericarditis, iridocyclitis, and erythrocyte

*The criteria for definite Still's disease comprise an onset of polyarthritis before the age of 16 years involving four or more joints for a minimum of 3 months; when less than four joints are involved, a biopsy of synovial membrane showing histology compatible with the diagnosis of rheumatoid arthritis (in the absence of other similar diseases such as polyarteritis nodosa, systemic lupus erythematosus, ankylosing spondylitis, psoriasis, or ulcerative colitis) may be regarded as diagnostic (Ansell and Bywaters, 1959). 
sedimentation rate. In addition, a general examination is made, noting in particular enlargement of the liver, spleen, or glands, and any rise in blood pressure. Routine tests include the erythrocyte sedimentation rate, haemoglobin, differential agglutination titre, latex fixation, and urinary protein and sugar; other tests are requested if indicated.

Should hepatomegaly, splenomegaly, proteinuria, or an inexplicably low haemoglobin be found at follow-up, screening tests for amyloidosis are performed. These include urine examination to exclude infection, 24-hour urinary protein excretion, blood urea, serum cholesterol, total serum protein, and fractionation by electrophoresis, as well as an intravenous pyelogram if indicated. Confirmatory evidence of amyloidosis is now usually obtained by rectal or renal biopsy, but in the past a Congo red test (Unger and others, 1948b) was routinely used.

\section{Results}

Sixteen cases of amyloidosis have been diagnosed among the 389 patients followed to 1966, an incidence of $4 \cdot 1$ per cent. (Table III). There were

TABLE III

INCIDENCE OF AMYLOIDOSIS IN PRESENT SERIES

\begin{tabular}{l|c|c|c|c|c}
\hline $\begin{array}{c}\text { Still's } \\
\text { Disease }\end{array}$ & Male & Female & $\begin{array}{c}\text { Total } \\
\text { Cases }\end{array}$ & \multicolumn{2}{c}{$\begin{array}{c}\text { Cases with } \\
\text { Amyloidosis }\end{array}$} \\
\cline { 2 - 5 } & No. & Per cent. \\
\hline Whole Series & 149 & 240 & 389 & 16 & $4 \cdot 1$ \\
\hline 10-year Follow-up & 83 & 126 & 209 & 9 & $4 \cdot 3$ \\
\hline
\end{tabular}

eight males and eight females, compared with the overall sex incidence of 149 males and 240 females. The course and previous treatment are shown in detail in Table IV (opposite). In an attempt to relate the amyloidosis to duration of disease, the follow-up 10 years from the onset was chosen; 209 case ( 83 male and 126 female) had reached this stage and the incidence of amyloidosis among them was 4.3 per cent.

In the whole series of 389 , there have been 21 deaths, seven due to amyloidosis and fourteen to other cases (Table V); post mortem examinations were performed in sixteen of the 21 cases. Amyloidosis was confirmed in the four cases diagnosed before death (Cases 2, 3, 5, and 7) and no other cases were found. The post mortem incidence was thus 25 per cent. Thioflavine-T and methyl violet staining was used for the histological review of kidney and liver in all cases.

The age at onset of the Still's disease in those who developed amyloidosis showed little difference from that in the group as a whole (Ansell and Bywaters, 1959), with a peak incidence of onset in the amyloid cases occurring before the age of 5 years. The diagnosis of amyloidosis was made from 1 to 23 years (mean 8.2) after the onset of disease (Table (VI). In three cases it was suspected clinically 1 to years before it could be confirmed by acceptable methods. In one of these patients (Case 1) suspicio

TABLE V

PROGNOSIS OF AMYLOIDOSIS IN PRESENT SERIES

\begin{tabular}{|c|c|c|c|c|c|c|c|}
\hline \multicolumn{3}{|c|}{ Still's Disease } & Total & Cases with & Death from & Death from & Total \\
\hline Whole Series .. & .. & . & 389 & 16 & 7 & 14 & 21 \\
\hline 10-year Follow-up & $\ldots$ & $\ldots$ & 209 & 9 & 1 & 11 & 12 \\
\hline
\end{tabular}

TABLE VI

DURATION OF STILL'S DISEASE AND AMYLOIDOSIS

\begin{tabular}{|c|c|c|c|c|c|c|c|}
\hline \multirow{2}{*}{ Outcome } & \multicolumn{3}{|c|}{ Still's Disease } & \multicolumn{2}{|c|}{ Amyloidosis Confirmed } & \multicolumn{2}{|c|}{$\begin{array}{l}\text { Duration at Follow-up } \\
\text { or Death (yrs) }\end{array}$} \\
\hline & $\begin{array}{l}\text { Case } \\
\text { No. }\end{array}$ & Sex & $\begin{array}{c}\text { Age at } \\
\text { Onset (yrs) }\end{array}$ & $\begin{array}{l}\text { Yrs after Onset of } \\
\text { Still's Disease }\end{array}$ & Method & Still's Disease & Amyloidosis \\
\hline Dead & $\begin{array}{l}1 \\
2 \\
3 \\
4 \\
5 \\
6 \\
7\end{array}$ & $\begin{array}{l}\mathbf{F} \\
\mathbf{M} \\
\mathbf{M} \\
\mathbf{M} \\
\mathbf{F} \\
\mathbf{F} \\
\mathbf{F}\end{array}$ & $\begin{array}{r}8 \\
3 \\
15 \\
10 \\
6 \\
3 \\
1\end{array}$ & $\begin{array}{r}6 \\
1 \\
4 \\
2 \\
1 \\
5 \\
20\end{array}$ & $\begin{array}{l}\text { Congo red } \\
\text { Lymph node } \\
\text { Renal biopsy } \\
\text { Congo red } \\
\text { Congo red } \\
\text { Congo red } \\
\text { Liver biopsy } \\
\text { Renal biopsy }\end{array}$ & $\begin{array}{r}13 \\
15 \\
14 \\
2 \\
23 \\
13 \\
14 \\
23\end{array}$ & $\begin{array}{c}7 \\
14 \\
10 \\
3 / 12 \\
12 \\
9 \\
3\end{array}$ \\
\hline Living & $\begin{array}{r}8 \\
9 \\
10 \\
11 \\
12 \\
13 \\
14 \\
15 \\
16\end{array}$ & $\begin{array}{l}\mathbf{M} \\
\mathbf{M} \\
\mathbf{M} \\
\mathbf{F} \\
\mathbf{F} \\
\mathbf{M} \\
\mathbf{F} \\
\mathbf{F} \\
\mathbf{M}\end{array}$ & $\begin{array}{r}12 \\
3 \\
10 \\
5 \\
8 \\
11 \\
4 \\
1 \\
1\end{array}$ & $\begin{array}{r}12 \\
23 \\
7 \\
16 \\
7 \\
8 \\
4 \\
8 \\
8\end{array}$ & $\begin{array}{c}\text { Congo red } \\
\text { Rectal biopsy } \\
\text { Rectal biopsy } \\
\text { Rectal biopsy } \\
\text { Renal biopsy } \\
\text { Congo red } \\
\text { Rectal biopsy } \\
\text { Congo red } \\
\text { Congo red } \\
\text { Rectal biopsy }\end{array}$ & $\begin{array}{r}17 \\
24 \\
9 \\
18 \\
13 \\
9 \\
14 \\
17 \\
8\end{array}$ & $\begin{array}{r}5 \\
1 \\
2 \\
2 \\
6 \\
1 \\
10 \\
9 \\
6 / 12\end{array}$ \\
\hline
\end{tabular}


TABLE IV

COURSE AND PREVIOUS TREATMENT OF SIXTEEN CASES WITH AMYLOIDOSIS COMPLICATING STILL'S DISEASE

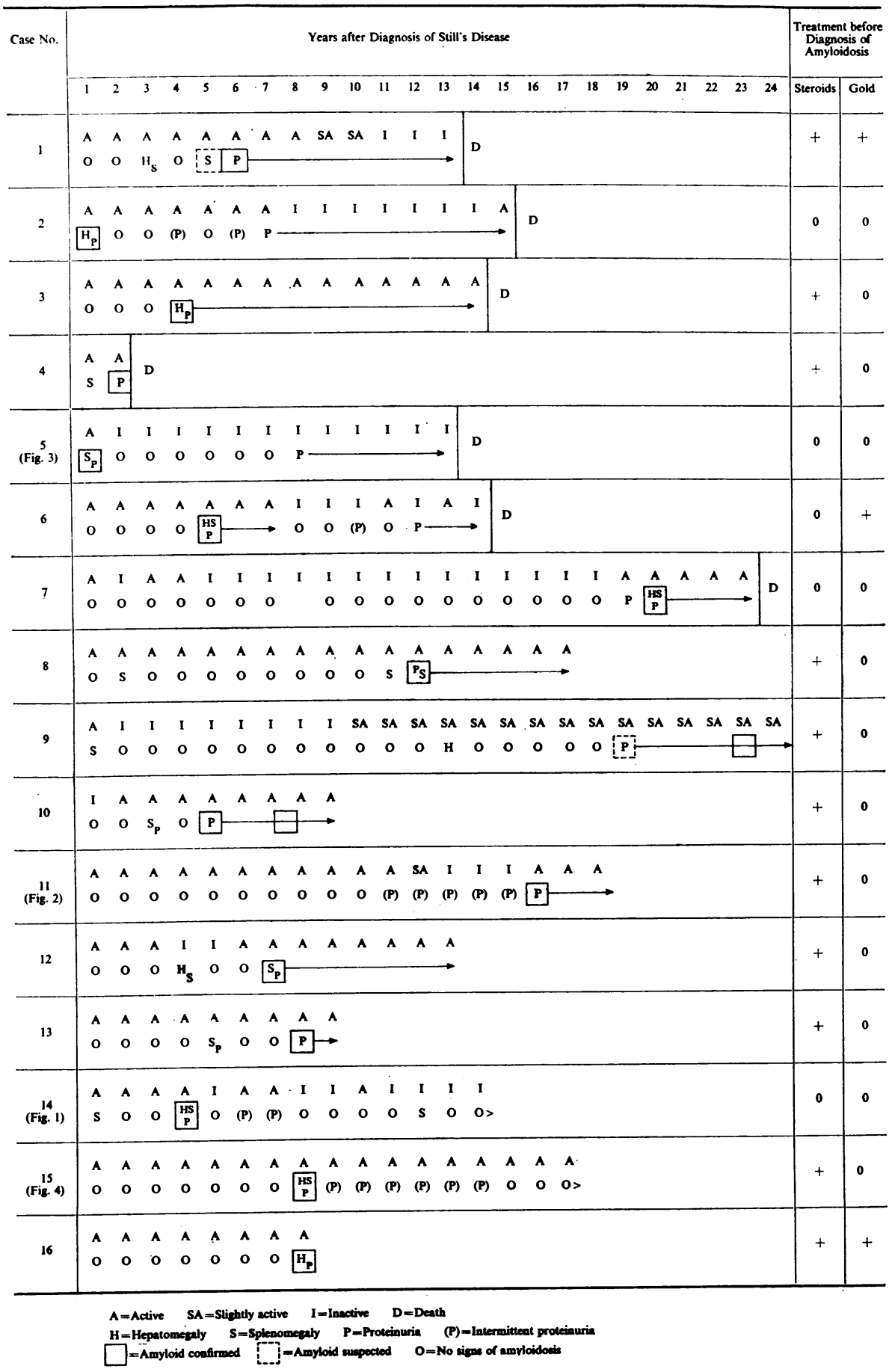


arose because of persistent splenomegaly without proteinuria and in the other two (Cases 9 and 10) because of continuous proteinuria. In the remaining thirteen cases the presenting sign of amyloidosis was proteinuria.

In the seven patients who died, amyloidosis had been present for from 4 months to 14 years (mean 8 years). As already indicated, the presence of amyloidosis was confirmed post mortem in the four cases in which it was performed. The Congo red test had been positive in two of the other three cases and liver biopsy in one. The living cases have had proven amyloidosis for from 6 months to 10 years (mean 4 years), confirmation having been obtained by rectal biopsy in five, renal biopsy in one, and by a positive Congo red test in the remaining three. At the time of diagnosis of amyloidosis, fifteen of the sixteen patients had active arthritis and the remaining one had had a recurrence of mild arthritis after some years of inactivity. Fourteen out of the sixteen showed no rheumatoid factor in the serum and in the eight in which it was performed the anti-nuclear factor was negative. The erythrocyte sedimentation rate and haemoglobin gave no clear correlation. At the time of confirmation of amyloidosis, eight patients had hepatomegaly and seven splenomegaly; proteinuria was present in all but the blood urea was normal (Table VII). The blood pressure was raised in two (Cases 9 and 10).

\section{Discussion}

The incidence of amyloidosis in this series is similar to that given by Lindbjerg (1964) but higher than in previously reported series of cases of Still's disease (Coss and Boots, 1946; Edström, 1958; Schlesinger and others, 1961: Table II). It is, however, similar to the results of Fearnley and
Lackner (1955) and Arapakis and Tribe (1963) in $\frac{7}{\sigma}$ adult rheumatoid arthritis (Table I).

Taken as a whole Still's disease has a better prognosis than adult rheumatoid arthritis because the disease tends to become inactive in a greater? proportion and because a good functional status is $\overrightarrow{\vec{\rho}}$ more often maintained (Ansell, 1965). The probability of survival, however, is influenced by the $\frac{C}{0}$ development of amyloidosis which is a potentially $\overline{\bar{\omega}}$. fatal complication; in this series of patients develop- $\widehat{\Phi}$ ing amyloid who died, the average duration of life after diagnosis was $8 \cdot 2$ years. This means that, in ${ }^{\infty}$ appraising patients for general management, surgery, $\vec{O}$ or subsequent training, proteinuria must always be $\overrightarrow{\vec{H}}$ specifically investigated.

It is very difficult to predict the development of amyloidosis in individual cases as there seems to be? little relationship between the duration and severity $N$ of Still's disease and the onset of amyloidosis; for? example Case 5 (see Appendix) illustrates the onset $\vec{\omega}$ of amyloidosis only one year after that of Still's ${ }^{2}$ disease which, although systemic in onset, left only mild residual joint involvement. In contrast, Case $\vec{z}$ 11 (see Appendix) was not confirmed until 16 yearsฏ after the onset, her illness having been one of $\stackrel{\circ}{\varsigma}$ continuous activity and severe destructive joint $\vec{\theta}$ involvement.

The suspicion of amyloidosis should arise if the is proteinuria, persistent hepatomegaly, or splenomegaly. The presence of proteinuria may be misleading as it can be due to other causes, such as infection, or after recovery from this, proteinuria due to amyloidosis may recur and not be recognized $\varrho$ as such. Hepatomegaly was present in 50 per cent. $\overrightarrow{\vec{O}}$ and splenomegaly in 43 per cent. of cases at the time 3 of diagnosis of amyloidosis, whereas in the acute? phase of Still's disease we have found these conditions? in $13 \cdot 8$ and 18 per cent. respectively.

TABLE VII

FINDINGS AT THE TIME OF DIAGNOSIS OF AMYLOIDOSIS

\begin{tabular}{|c|c|c|c|c|c|c|}
\hline $\begin{array}{l}\text { Case } \\
\text { No. }\end{array}$ & $\begin{array}{c}\text { Differential } \\
\text { Agglutination } \\
\text { Titre }\end{array}$ & $\begin{array}{l}\text { Erythrocyte } \\
\text { Sedimentation } \\
\text { Rate (mg./hr) }\end{array}$ & $\underset{\text { (per cent.) }}{\mathrm{Hb}}$ & $\begin{array}{c}\text { Enlarged } \\
\text { Liver Spleen }\end{array}$ & $\begin{array}{c}\text { Urinary } \\
\text { Protein } \\
\text { (mg. per cent.) }\end{array}$ & $\begin{array}{c}\text { Blood } \\
\text { Urea } \\
\text { (mg. per cent.) }\end{array}$ \\
\hline $\begin{array}{r}1 \\
2 \\
3 \\
4 \\
5 \\
6 \\
7 \\
8 \\
9 \\
10 \\
11 \\
12 \\
13 \\
14 \\
15 \\
16\end{array}$ & 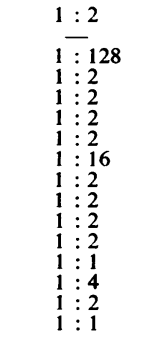 & $\begin{array}{r}60 \\
64 \\
20 \\
123 \\
55 \\
110 \\
107 \\
86 \\
67 \\
97 \\
107 \\
27 \\
100 \\
64 \\
23 \\
60\end{array}$ & $\begin{array}{r}\overline{90} \\
110 \\
87 \\
62 \\
63 \\
56 \\
95 \\
77 \\
97 \\
90 \\
66 \\
90 \\
52 \\
61 \\
57\end{array}$ & $\begin{array}{ll}+ & 0 \\
+ & 0 \\
+ & 0 \\
0 & 0 \\
0 & + \\
+ & + \\
+ & + \\
\mathbf{0} & + \\
0 & 0 \\
0 & 0 \\
0 & 0 \\
0 & + \\
0 & 0 \\
+ & + \\
+ & + \\
+ & + \\
+ & 0\end{array}$ & $\begin{array}{r}120 \\
+ \\
750 \\
800 \\
500 \\
250 \\
250 \\
200 \\
1000 \\
400 \\
500 \\
300 \\
300 \\
1000 \\
60 \\
70\end{array}$ & $\begin{array}{l}20 \\
34 \\
18 \\
30 \\
17 \\
32 \\
34 \\
25 \\
62 \\
19 \\
27 \\
17 \\
35 \\
32 \\
30\end{array}$ \\
\hline
\end{tabular}


Even when one suspects amyloidosis, its presence may be very difficult to prove.

Confirmation has been complicated in the past by the interpretation of the Congo red test, and in patients with apparently uncomplicated rheumatoid arthritis an increased uptake of the dye has been found (Dixon, Ramcharan, and Ropes, 1955). Furthermore, it is well known that a negative Congo red test may be coincident with positive histological findings (Blum and Sohar, 1962). More recently, renal biopsy has been used; this remains the only sure method of confirming renal involvement, but is a potentially dangerous procedure especially in children, and we prefer rectal biopsy as the initial screening test. Ennevaara and Martti (1964) found a close relationship between the results of these two investigations, only one out of eight showing amyloidosis on renal histology being negative on rectal biopsy.

The duration, severity, and activity of Still's disease varies from case to case. In this Unit, the aim of treatment is to achieve a functional state wherein the child can live at home and attend school during the period or periods of activity with such continuing supervision that when the disease burns out he is left with a minimum of residual damage and with normal development of body and mind. Treatment is in the main conservative, consisting of daily physiotherapy, rest splints to prevent contractures, serial splints to help improve deformities, and analgesics. Many children are well managed on salicylates. However, if activity persists, chloroquine or gold therapy and sometimes steroid therapy may be added. The only absolute indication for corticosteroid therapy is severe eye involvement, but it may also be needed in some patients who are systemically ill or do not respond to a conservative regime.

On the basis of animal studies performed by Teilum (1952), cortisone was thought to be conducive to the development of amyloidosis. Injections of casein given to mice for several weeks in amounts insufficient to produce amyloidosis and followed by a few injections of cortisone resulted in the prompt appearance of amyloid in the spleen. However, in further experiments, Bestetti, Pirani, and Catchpole (1958) reported that, if cortisone were given before or during casein treatment, the formation of amyloid was reduced or prevented. Gardner (1962), comparing the post mortem incidence of amyloidosis in patients with rheumatoid arthritis in the precortisone and cortisone era, found a $9 \cdot 3$ and $12 \cdot 5$ per cent. incidence respectively, but such studies are subject to several sources of bias. In our series eleven of the sixteen had had corticosteroids before amyloidosis was diagnosed; this probably reflects the severity of the disease process. In cases with proven amyloidosis we have found that corticosteroids had no beneficial effect on the arthritis or the nephrotic syndrome, and in one the oedema became worse.

The problem of gold therapy is equally complex as in experimental animal studies Kirkpatrick and Sorenson (1965) have shown that casein-induced amyloidosis in mice previously treated with colloidal gold was greater than in a non-treated control group. Three of our patients had had gold therapy before amyloidosis was diagnosed, 4 years previously in Case 1 and 3 years in Case 6; in Case 16 proteinuria was noted for the first time during a course of gold. Chrysotherapy has been given to Cases 2 and 7 after amyloidosis was diagnosed in an attempt to control the activity of the Still's disease, but had little effect on either the disease process or the amyloidosis.

Four of our cases $(2,5,7$, and 14), however, had had neither corticosteroid nor gold therapy before amyloidosis was diagnosed, and it is, therefore, difficult to implicate either form of treatment in the genesis or development of amyloidosis.

Bland and Duarte (1963), following an earlier report, treated a patient with rheumatoid arthritis with whole liver extract, and although the symptoms of amyloidosis improved a repeat renal biopsy showed no change in the amyloid infiltration.

Clinical remission of amyloidosis was reported by Parkins and Bywaters (1959); this patient who appears as Case 6 in this series following a recurrence of proteinuria died 3 years later in uraemia. We have seen remission in three other cases $(5,14$, and 15). Case 14 (see Appendix) developed amyloidosis after 4 years of active arthritis and in the next 3 years proteinuria recurred intermittently. Since then, the nephrotic syndrome has regressed, the serum protein has returned to normal, and the proteinuria has gone; the joint disease has been inactive for 6 of these 7 years. Case 15 (see Appendix) developed amyloidosis after 8 years of active arthritis, but in the following 6 years proteinuria was intermittent and has now regressed although the arthritis remains active. This last case is the only instance of remission of amyloidosis in this group associated with continued activity of Still's disease.

Thus, to summarize our therapeutic efforts: in the absence of curative agents, we have been unable to prevent the progress of amyloidosis in patients with active disease, although much can be done symptomatically with diuretics and high protein diet for renal disease; we have no evidence that such control of rheumatoid arthritis as we are able to achieve 
with gold, steroids, and other anti-inflammatory agents is effective in the prevention of amyloid accumulation although we have a belief that, if the disease becomes inactive spontaneously, the progression of amyloidosis is halted. In this situation, faced with a potentially fatal process, we have started to investigate the effects of cytotoxic drug therapy.

\section{Summary}

(1) Among 389 cases of Still's disease followed up for 1 to 25 years (mean 10.9), sixteen cases of amyloidosis were diagnosed, giving an overall incidence of $4 \cdot 1$ per cent. At 10 years from the onset of the disease in 209 patients, nine $(4 \cdot 3$ per cent.) had developed amyloidosis. The mean duration of Still's disease at the time of diagnosis of amyloidosis was $8 \cdot 2$ years (range 1 to 23 ).

(2) Amyloidosis was suspected by the presence of proteinuria, hepatomegaly, or splenomegaly, and was confirmed in the past by the intra- venous Congo red test and more recently by renal or rectal biopsy.

(3) Of the sixteen cases, seven died from 4 months $\frac{7}{\omega}$ to 14 years (mean 8) after the diagnosis of amyloidosis. The remaining nine are still alive, $\underset{\sim}{\stackrel{5}{+}}$ the mean duration of confirmed amyloidosis $\overline{0}$ being 4 years (range 6 months to 10 years).

(4) No definite correlation has been found between previous treatment with corticosteroids or gold and the subsequent formation of amyloid. As yet no satisfactory treatment for amyloidosis is $\overrightarrow{0}$ available.

\section{ADDENDUM}

Since this study was begun, three of the cases. recorded in this paper have died, and three further cases of amyloidosis have developed among the $389 \vec{\omega}$ patients. A 15-year follow-up of 140 cases in the 0

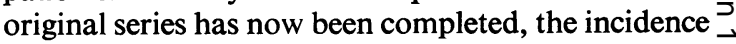
of amyloidosis at that point in time being 6.4 per 3 cent.

\section{APPENDIX}

Case 14 (Fig. 1), showing course in a female patient in whom the Still's disease has gone into remission and the amyloidosis appears to have regressed.

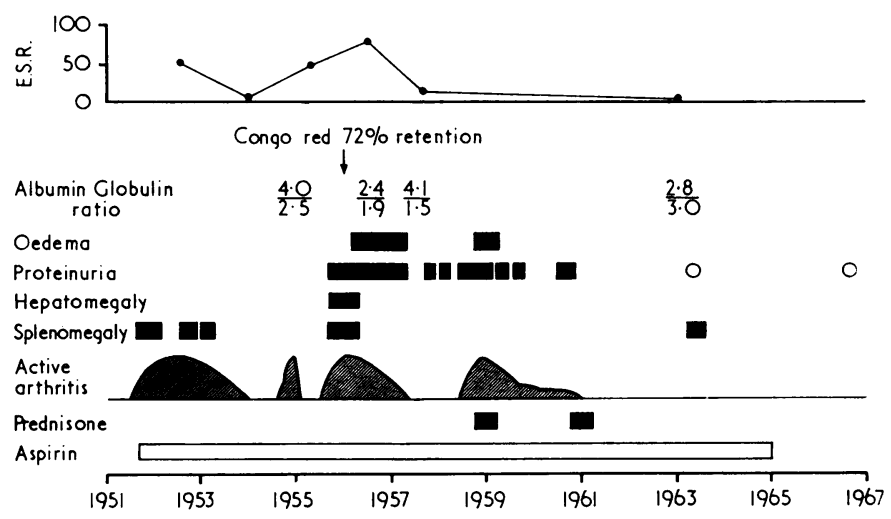


Case 11 (Fig. 2), showing prolonged severe activity of the disease in a female patient treated with corticosteroids, who during a period of relative remission developed proteinuria. Amyloidosis was diagnosed from which she has since died.

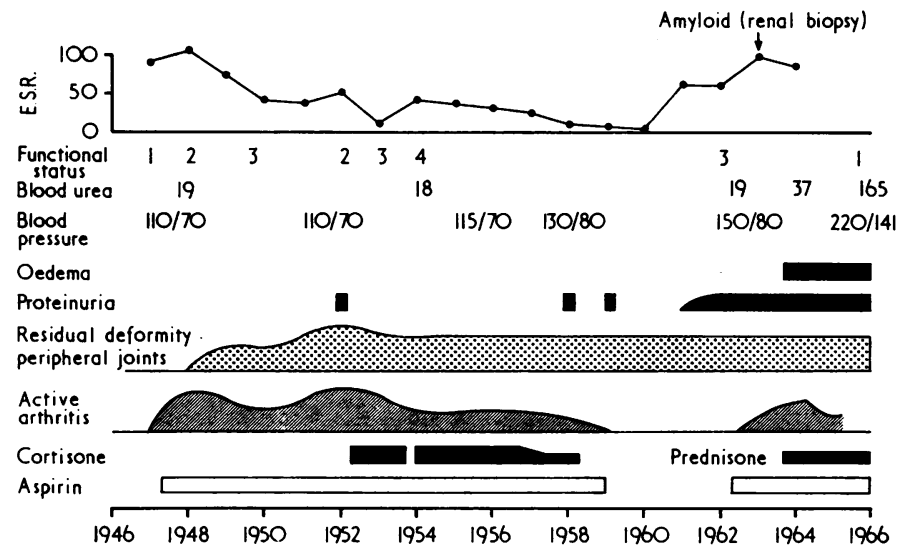

Case 5 (Fig. 3), showing acute systemic Still's disease remitting within 2 years, in a female patient who subsequently developed a nephrotic syndrome without any recurrence of activity of the arthritis and subsequently died of uraemia with a partial renal vein thrombosis and wide-spread amyloidosis, 13 years after the onset. At post mortem amyloidosis was found in the vessels of the heart, liver, spleen, adrenals, and left kidney.

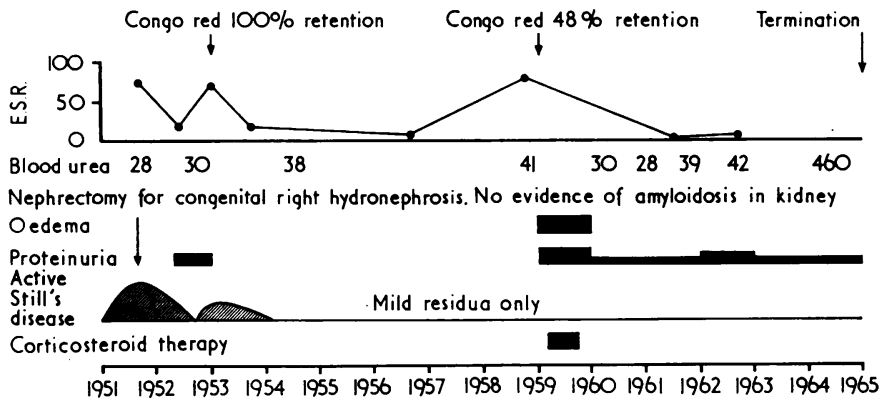

Case 15 (Fig. 4), showing transient proteinuria associated with a positive Congo red test with no apparent deterioration over a 9-year period.

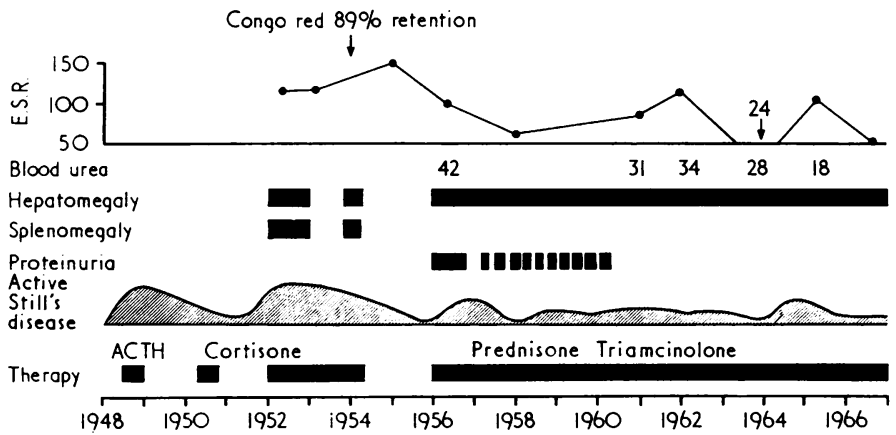




\section{REFERENCES}

Ansell, B. M. (1965). In "Progress in Clinical Rheumatology”, ed. A. St. J. Dixon, p. 95. Churchill, London.

and Bywaters, E. G. L. (1959). Bull. rheum. Dis., 9, 189 (Prognosis in Still's disease).

Arapakis, G., and Tribe, C. R. (1963). Ann. rheum. Dis., 22, 256 (Amyloidosis in rheumatoid arthritis investigated by means of rectal biopsy).

Bestetti, A., Pirani, C. L., and Catchpole, H. R. (1958). Arthr. and Rheum., 1, 274 (Studies on experimental amyloidosis).

Bland, J. H., and Duarte, C. G. (1963). Ibid., 6, 262 (Rheumatoid arthritis and renal amyloidosis. Report of a case treated with whole liver extract for 3 years).

Blum, A., and Sohar, E. (1962). Lancet, 1, 721 (The diagnosis of amyloidosis-Ancillary procedures).

Clinical Pathological Conference, Boston (1959). J. Pediat., 54, 379.

Clinico-pathological Conference, Hammersmith Hospital (1964). Brit. med. J., 2, 1384 (A case of Still's disease with amyloidosis, demonstrated at the Postgraduate Medical School of London).

Coss, J. A., and Boots, R. H. (1946). J. Pediat., 29, 143 (Juvenile rheumatoid arthritis: a study of 56 cases with a note on skeletal changes).

Dixon, A. St. J., Ramcharan, S., and Ropes, M. W. (1955). Ann. rheum. Dis., 14, 51 (Rheumatoid arthritis: dye retention studies and comparison of dye and radioactively labelled red cell methods for measurement of blood volume).

Edström, G. (1958). Arthr. and Rheum., 1, 497 (Rheumatoid arthritis and Still's disease in children. A survey of 61 cases).

Ennevaara, K., and Martti, O. (1964). Ann. rheum. Dis., 23, 131 (Rheumatoid arthritis with amyloidosis).

Fearnley, G. R., and Lackner, R. (1955). Brit. med. J., 1, 1129 (Amyloidosis in rheumatoid arthritis, and significance of "unexplained" albuminuria).

Gardner, D. L. (1962). Ann. rheum. Dis., 21, 298 (Amyloidosis in rheumatoid arthritis treated with hormones).

James, J. A., and Bolton, F. G. (1951). Ibid., 10, 250 (Amyloidosis in Still's disease).

Kirkpatrick, J. B., and Sorenson, G. D. (1965). Exp. molec. Path., 4, 627 (Experimental amyloidosis. IV. Effect of colloidal gold on the development of amyloidosis).

Lindbjerg, I. F. (1964). Arch. Dis. Childh., 39, 576 (Juvenile rheumatoid arthritis. A follow-up of 75 cases).

Missen, G. A. K., and Taylor, J. D. (1956). J. Path. Bact., 71, 179 (Amyloidosis in rheumatoid arthritis).

Parkins, R. A., and Bywaters, E. G. L. (1959). Brit. med. J., 1, 536 (Regression of amyloidosis secondary to rheumatoid arthritis).

Reece, J. M., and Reynolds, T. B. (1954). Amer. J. med. Sci., 228, 554 (Amyloidosis complicating rheumatoid arthritis).

Rosenberg, E. F., Baggenstoss, A. H., and Hench, P. S. (1944). Ann. intern. Med., 20, 903 (The causes of death in 30 cases of rheumatoid arthritis).

Schlesinger, B. E., Forsyth, C. C., White, R. H. R., Smellie, J. M., and Stroud, C. E. (1961). Arch. Dis. Childh., 36, 65 (Observations on the clinical course and treatment of 100 cases of Still's disease).

Teilum, G. (1952). Ann. rheum. Dis., 11, 119 (Cortisone-ascorbic acid interaction and the pathogenesis of amyloidosis; mechanism of action of cortisone on mesenchymal tissue).

— and Lindahl, A. (1954). Acta med. scand., 149, 449 (Frequency and significance of amyloid changes in rheumatoid arthritis).

Trasoff, A., Schneeberg, N., and Scarf, M. (1944). Arch. intern. Med., 74, 4 (Recovery from multiple rheumatoid arthritis complicated by amyloidosis in a child).

Unger, P. N., Zuckerbrod, M., Beck, G. J., and Steele, J. M. (1948a). Amer. J. med. Sci., 216, 51 (Amyloidosis in rheumatoid arthritis. A report of 10 cases).

$-\underset{-}{-},--(1948 \mathrm{~b})$. J. clin. Invest., 27, 111 (Study of the disappearance of Congo red from the blood of non-amyloid subjects and patients with amyloidosis). 
La mortalité et le pronostic au cours de l'amyloïdose compliquant la maladie de Still

\section{RÉSUMÉ}

1. Parmi 389 cas de maladie de Still, suivis pendant 1 à 25 ans $(10,9$ ans en moyenne) on reconnut 16 cas d'amyloïdose, ce qui donne une incidence totale de 4,1 pour cent. Dix ans après le début de la maladie chez 209 sujets, neuf d'entre eux développérent une amyloïdose.

La durée moyenne de la maladie de Still lors du diagnostic de l'amyloïdose était de 8, 2 ans (entre 1 et 23 ans.).

2. On soupçonnait l'amyloïdose en présence de l'albuminurie, de l'hépatomégalie ou de la splénomégalie et on la confirmait par le test au rouge Congo intraveineux et, plus récemment, par la biopsie rénale ou rectale.

3. Sept sur 16 cas décédèrent entre le quatrième mois et la quatorzième année ( 8 ans en moyenne) après le diagnostic de l'amyloïdose. Les 9 autres sont encore en vie, la durée de l'amyloïdose confirmée étant de 4 ans en moyenne ( 6 mois à 10 ans).

4. On ne trouva aucune corrélation précise entre la thérapie par des corticostéroïdes ou par des sels d'or et la formation de la dégénérescence amyloïde. A l'heure actuelle on ne dispose pas de traitement satisfaisant de l'amyloïdose.
La mortilalidad y el pronóstico en casos de amiloidosis complicando la enfermedad de Still

\section{SUMARIO}

1. Entre 389 casos de enfermedad de Still seguidos durante uno a 25 años (un promedio de 10,9 años) se reconocieron 16 casos de amiloidosis, lo que da una incidencia total de 4,1 por ciento. Diez años después del comienzo de la enfermedad en 209 sujetos, nueve de ellos desarrollaron una amiloidosis.

La duración media de la enfermedad de Still al momento del diagnóstico de la amiloidosis fué de 8, 2 años (de uno a 23 años).

2 . Se sospechó la amiloidosis en presencia de albuminuria, de hepatomegalia o de esplenomegalia ye se la confirmó con la prueba del rojo de Congo intravenoso $\mathrm{y}$, más recientemente, por la biopsia renal o rectal.

3. De los 16 casos, siete murieron entre el cuarto mes y el décimo-cuarto año (un promedio de 8 años) después de diagnosticar la amiloidosis. Los demás nueve viven todavía, la duración media de la amiloidosis confirmada siendo de un promedio de cuatro años (6 meses a 10 años).

4. No se encontró correlación definida entre el tratamiento con corticosteroides o con sales de oro y la formación consiguiente de degeneración amiloidea. No se conoce todavía un tratamiento satsfactorio de la amiloidosis. 